\title{
Discourses of Writing and Learning to Write
}

\author{
Roz Ivanic \\ Literacy Research Centre, Department of Linguistics and Modern English \\ Language, Lancester University, Lancaster LA 1 4YT, UK
}

This paper presents a meta-analysis of theory and research about writing and writing pedagogy, identifying six discourses - configurations of beliefs and practices in relation to the teaching of writing. It introduces and explains a framework for the analysis of educational data about writing pedagogy in which the connections are drawn across views of language, views of writing, views of learning to write, approaches to the teaching of writing, and approaches to the assessment of writing. The framework can be used for identifying discourses of writing in data such as policy documents, teaching and learning materials, recordings of pedagogic practice, interviews and focus groups with teachers and learners, and media coverage of literacy education. The paper also proposes that, while there are tensions and contradictions among these discourses, a comprehensive writing pedagogy might integrate teaching approaches from all six.

Keywords: discourses, writing, literacy, analytical framework, learning, teaching

\section{Introduction}

My aim is to present and explain a framework which I have developed for the analysis of a variety of types of data concerned with the teaching of writing: data such as policy documents, teaching and learning materials, recordings of pedagogic practice, interviews and focus groups with teachers and learners, and media coverage of literacy education. I propose that such data can be analysed for evidence of the underlying beliefs of those from whom it originated. Policy, practice and opinions about literacy education are usually underpinned, consciously or subconsciously, by particular ways of conceptualising writing, and by particular ways of conceptualising how writing can be learned. These different ways of conceptualising literacy lie at the heart of 'discourses' in the broadest sense: recognisable associations among values, beliefs and practices which lead to particular forms of situated action, to particular decisions, choices and omissions, as well as to particular wordings. The ways in which people talk about writing and learning to write, and the actions they take as learners, teachers and assessors, are instantiations of discourses of writing and learning to write: the purpose of this paper is to identify these discourses.

I start by mentioning briefly the work of others who have discussed theories, metaphors, ideologies and discourses which underpin pedagogic practice in literacy education. I then present a view of language consisting of four interdependent layers, drawing on Fairclough (1989, 1992a), Ivanič (1998) and Jones (1990). The main part of the paper uses this view of language to structure the identification of six 'discourses of writing and learning to write' consisting of sets of beliefs about writing and learning to write, and practices of teaching and 
assessment of writing associated with these beliefs. Much of what I present in these sections has been discussed in greater detail elsewhere. I will do no more than outline the features of each set of beliefs and practices, since my purpose is to discuss how they compare with and relate to one another in the constitution of recognisable discourses of writing. Since the main aim of this paper is to present a comprehensive framework, it is impossible to exemplify each section. However, in the conclusion I discuss how the framework can be applied to the study of a range of data concerning the learning and teaching of writing, and the discourses at work in these practices, and suggest how it can be extended to apply to the study of pedagogy where the teaching of writing is not separated from other aspects of literacy. I end by proposing that the view of language introduced at the beginning of the paper implies a more comprehensive and integrated view of the nature of writing and learning to write, which has the capacity to generate a writing pedagogy which combines elements from all the approaches to the teaching of writing discussed here.

\section{Other Work on Views of Literacy Underpinning Policy and Practice}

Sealey has reviewed and critiqued the theories of language underpinning policy documents concerned with language in primary education: the National Curriculum for English. The National Literacy Strategy, and The Initial Teacher Training National Curriculum for Primary English (1997, 1999a,1999b; Bourne et al., 1999). She has shown how recent understandings about the social nature of language and literacy have not been taken into account in these curriculum documents, and how the views of language and language learning underpinning the curricula are thus narrow and may lead to misunderstandings for teachers and learners. Her work is exemplary in that she takes the policy documents as a starting point, identifies the theories of language, language learning and pedagogy on which they are based, and discusses gaps and alternatives to these. She draws on a wide knowledge of linguistic and pedagogic theory, but does not offer a framework for undertaking similar analyses of other data.

In The New Literacy Studies a distinction has been drawn between, on the one hand, asocial conceptualisations of literacy as autonomous, decontextualised skills located in the individual and, on the other hand, conceptualisations of literacy as social practices, culturally situated and ideologically constructed (see e.g. Barton, 1994; Baynham, 1995; Street, 1984). Attention has been drawn to metaphors of (il)literacy and the way in which different metaphors evoke different responses in policy and practice (Levine 1985: 172, quoted and updated in Barton 1994: 13). The framework I am presenting here builds on this work, developing more nuanced distinctions among six ways of conceptualising writing, and connecting them to particular pedagogical traditions.

Hannon (2000) in his book Reflecting on Literacy in Education devotes one chapter each to theories about the nature of literacy, theories of literacy development, and theories of literacy teaching. He presents these as theories which must be taken into account in decision making about practice in the teaching of literacy. These chapters complement the framework I am presenting here by discussing in detail some, but not all, of the distinctions I present in this paper. The 
chapters on literacy development and literacy teaching also provide some additional perspectives, especially regarding early literacy development.

Lea and Street (1998) have proposed, on the basis of research on literacy in higher education in the UK, that there are three beliefs about academic literacy underlying policy and practice in support for student writing. According to Lea and Street, 'Study Skills' is a conceptualisation of literacy based on the belief that there is a body of knowledge and a set of skills for academic literacy which can be taught independently of context, and transferred to the different contexts in which students need to write, and consequently that students need to be taught generic, technical aspects of writing. 'Academic Socialisation' is a conceptualisation of literacy based on the belief that there are different literacies in different contexts, so that students need to learn the specific characteristics of academic writing, and of the disciplinary culture into which they are entering. 'Academic Literacies' is a conceptualisation of literacy based on the beliefs that literacies are heterogeneous, are shaped by interests, epistemologies and power relations, have consequences for identity, and are open to contestation and change. They claim that, in practice, each of these conceptualisations of literacy incorporates the pedagogic practices of the one before, but adds something more to it, so that, for example, 'academic socialisation' as a belief underlying practice includes the teaching of technical aspects of literacy but does so in the context of teaching also about the specific characteristics of literacies associated with different disciplines.

Aspects of each of the above overlap with the framework I am proposing in this paper (see Lillis, 2003, for a discussion of ways in which the three-way distinction proposed by Lea and Street maps on to this framework). What I hope to achieve here is a more comprehensive framework and a more fine-grained set of distinctions which are not specific to one particular sector of education, but can be used as a tool for analysis of data about the teaching and learning of writing in a wide range of formal and informal settings.

\section{A Multi-layered View of Language}

As discussed in Fairclough $(1989,1992 a)$, Ivanič (1998) and Jones (1990), a comprehensive view of language treats the textual aspects of language as embedded within, and inseparable from, mental and social aspects. I am using the metaphor of 'layers' to capture this sense of embeddedness, and Figure 1 shows each 'layer' surrounding a smaller one, like the skins of an onion (although I have chosen to use 'boxes' rather than circles in the diagram to maintain a sense that a 'text' is at the centre). Terms such as 'aspects', 'dimensions', 'elements' or 'facets' could also be used, but they do not imply embeddedness in the way the term 'layers' does. Figure 1 is a variation on those presented by Jones, Fairclough and Ivanič, distinguishing four layers which I believe are salient for identifying discourses of writing and learning to write. A great deal has already been written about these different aspects of language, and I provide only a brief sketch of them here as a backdrop to the framework which I present in the following sections.

At the centre of a multi-layered view of language is 'text', as seen in Figure 1. This, at its narrowest, consists only of the linguistic substance of language. A 
4: Sociocultural and political context

\section{3: Event}

2: Cognitive processes

1: Text

Figure 1 A multi-layered view of language

great deal of computer-aided language study is limited to this aspect of language, since turning texts into a machine-readable form inevitably divests them of all but their linguistic substance. 'Text' can also be viewed as multimodal, including visual and material as well as linguistic characteristics of written text (see Kress \& van Leeuwen, 1996, 2001; Ormerod \& Ivanič, 2002; van Leeuwen, 1998).

A somewhat broader view of language includes what is happening in the minds of the people who are involved in producing and comprehending language - layer 2 in Figure 1. This is the focus of a great deal of work in psycholinguistics. The focus in this layer is not so much on 'language' as an object, more on 'languaging': the mental processes of meaning-making, and in relation to multimodal meaning-making, the focus is on 'design' (see Cope \& Kalantzis, 2000; Kress \& van Leeuwen, 2001). The cognitive processes and strategies involved in language use are often studied independently of the texts at the centre of these processes and strategies, but the existence of the texts is implicit in the study of their production and reception.

A comprehensive view of language also includes social aspects of language production and reception - Layers 3 and 4 in Figure 1. Layer 3, labelled 'Event', refers to the observable characteristics of the immediate social context in which language is being used, including the purposes for language use, the social interaction, the particulars of time and place. This is what Halliday (1994; Halliday \& Hasan, 1989) calls 'the context of situation'. It is the focus of interest for 
pragmatics, for social interactionist accounts of language, and for field work in ethnographies of communication and of literacy.

The outer layer of a comprehensive, social view of language consists of the socioculturally available resources for communication: the multimodal practices, discourses and genres which are supported by the cultural context within which language use is taking place, and the patterns of privileging and relations of power among them (see e.g. Cope \& Kalantzis, 2000; Fairclough, 1992a). A focus on these aspects of language includes also attention to the views of the world and social structures which interact with language practices, discourses and genres (views of the world and social structures are treated as a separate layer in the diagrams in Fairclough, 1992a and Ivanič, 1998). This is what Halliday refers to as 'the context of culture'. It is the focus of interest for those taking a social constructionist view of language and communication. This outer layer goes beyond the material facts of language and language use (represented by layers 1-3) to identify why they are the way they are, sometimes also with a sociopolitical agenda for contestation of the status quo and action for change.

\section{Introduction to the 'Discourses of Writing' Framework}

Figure 2 uses the multi-layered view of language presented above as a starting point for identifying different discourses of writing. Using Gee's definition of a 'discourse' as 'a socially accepted association among ways of using language, other symbolic expressions, and "artifacts", of thinking, feeling, believing, valuing, and of acting which can be used to identify oneself as a member of a socially meaningful group' (Gee, 1996: 131), I am defining 'discourses of writing' as constellations of beliefs about writing, beliefs about learning to write, ways of talking about writing, and the sorts of approaches to teaching and assessment which are likely to be associated with these beliefs. I am proposing, also along the lines of Gee's definition, that participating in one or more of these discourses positions people who talk about or teach writing in these ways, identifying them with others who think, speak, write and act from within the same discourse. However, social action is not wholly determined by socially available discourses: human agents are continuously recombining and transforming discoursal resources as they deploy them for their own purposes (as argued by, for example, Kress, 1996, 1997). Actual instantiations of discourses are not always homogenous, but are often discoursally hybrid, drawing on two or more discourses.

I have developed this framework over a number of years by working to and fro between evidence of pedagogic practices, evidence of beliefs, and theories of language and literacy. On the one hand I became aware that there are a number of distinct approaches to the teaching of writing, and so I began to think about the assumptions about the nature of writing and learning to write on which they are based. On the other hand, I became aware of distinct theories of language and literacy, and began to think about the sorts of pedagogic practices that each implied. Since the theory and evidence on which the framework is based are drawn almost entirely from research and practice on writing pedagogy in Anglophone countries, its relevance may be limited to similar contexts. However, I hope it might act as a catalyst for those working in other countries and contexts to refine, revise or develop the framework to extend its scope. 


\begin{tabular}{|c|c|c|c|c|c|c|c|}
\hline 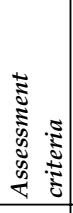 & & 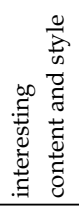 & & م. & 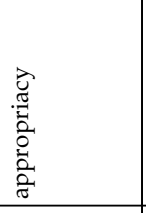 & 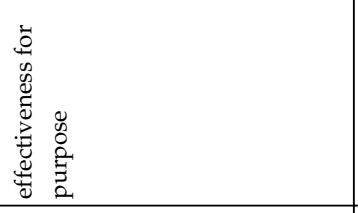 & 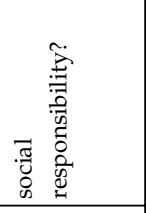 \\
\hline 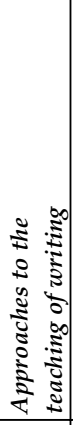 & 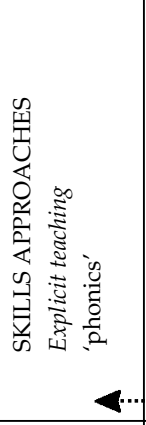 & 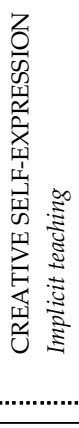 & 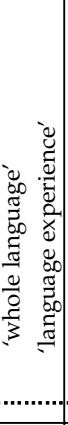 & 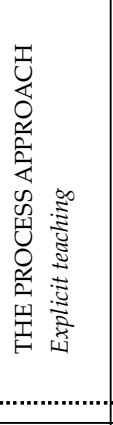 & 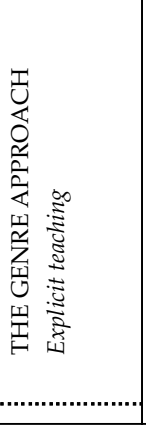 & 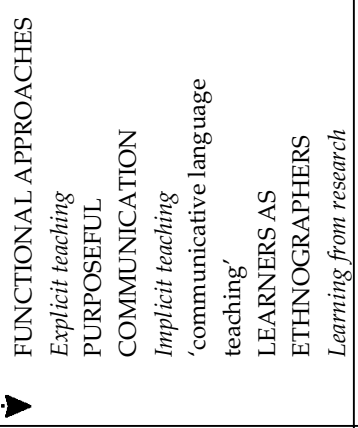 & 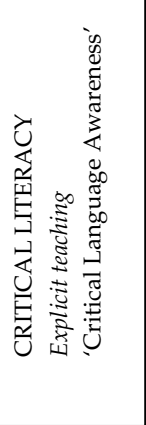 \\
\hline 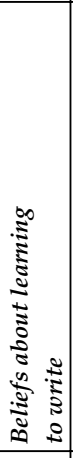 & 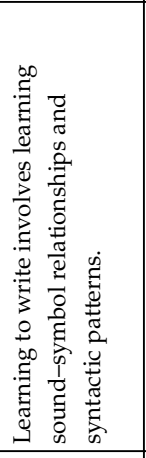 & 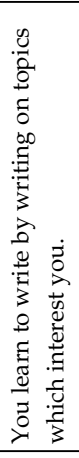 & & 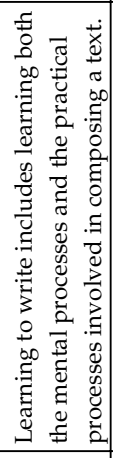 & 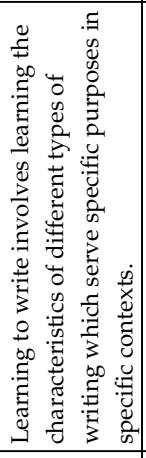 & 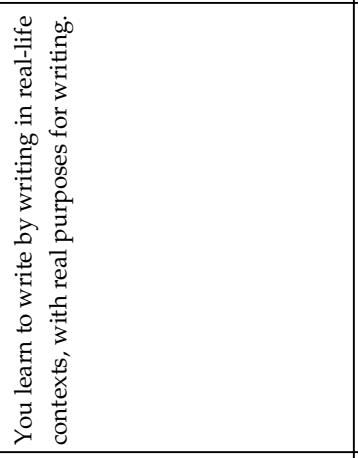 & 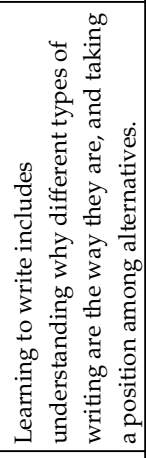 \\
\hline 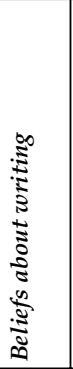 & 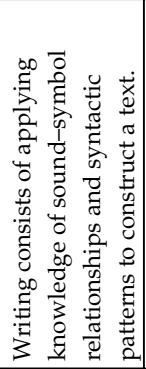 & 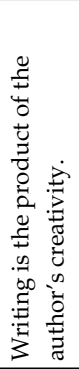 & & 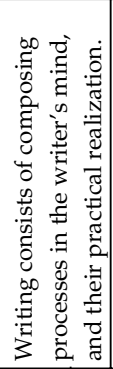 & 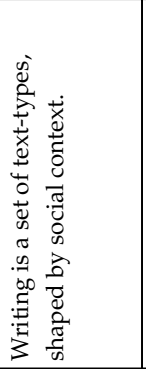 & 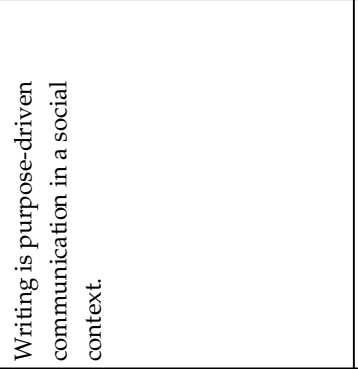 & 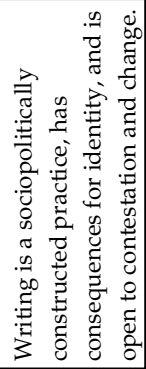 \\
\hline 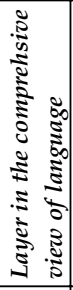 & \multicolumn{6}{|c|}{ 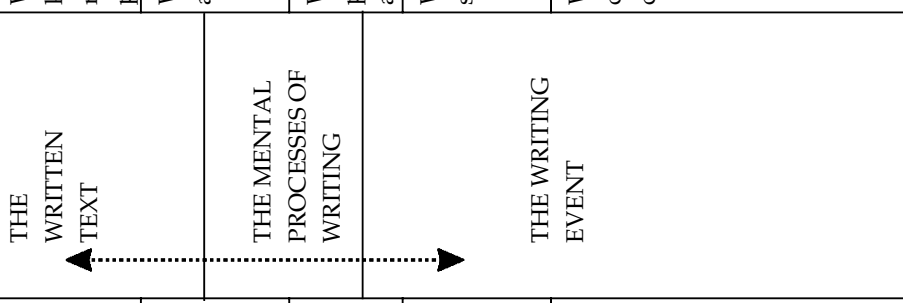 } & 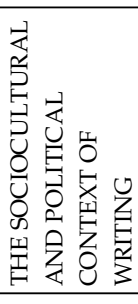 \\
\hline 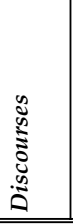 & 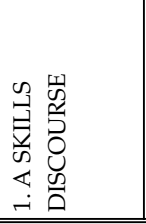 & 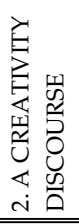 & & 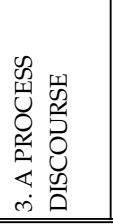 & 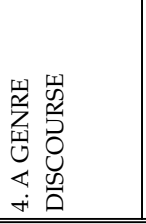 & 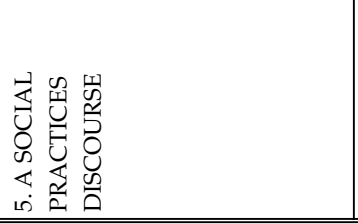 & 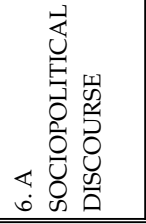 \\
\hline
\end{tabular}


The first column lists the six discourses of writing and learning to write which I discuss in the main part of the paper. ${ }^{1}$ The next column shows which layer of the multilayered view of language described in the previous section is the focus of attention for the beliefs and practices presented in each row. For example, in the row for $A$ sociopolitical discourse of writing, I am suggesting that the beliefs and practices which constitute this discourse take into account 'the sociocultural and political context of writing'. In some cases I am suggesting that one layer in the comprehensive view of language has generated two or more sets of beliefs and approaches: for example, there are three distinguishable discourses of writing and learning to write associated with 'the writing event'. In some cases I am suggesting that a discourse spans two layers; for example, A process discourse of writing spans both 'the mental processes of writing' and aspects of 'the writing event'. While the beliefs about writing and about learning to write do not necessarily line up neatly, I have put them together in the matrix on the grounds that there are many commonalities in the two sets of beliefs, and that they belong to the same overarching discourse.

I had difficulty in deciding where to place the distinctions among 'explicit', 'implicit', and 'learning from research'. These distinctions straddle the dividing line between learning and teaching; they are both part of beliefs about how writing is learnt and part of approaches to teaching. Particularly, the word 'explicit' implies some form of teaching, whereas 'implicit' and 'from research' are means of learning which do not necessarily imply teaching. For neatness in the framework, I decided to place these distinctions all in the 'approaches to teaching' column, since this is an area in which teachers have to make decisions, and those decisions are, in my view, part and parcel of the approach to teaching. I will discuss this interplay between beliefs about learning to write and approaches to the teaching of writing as it arises.

I am proposing that the framework can be used as a research tool to identify distinct discourses which may be instantiated relatively homogeneously or in various combinations in expressed beliefs, in particular elements in the practice of the teaching and assessment of writing, and in policy and curriculum documents. Each row in the framework represents what I believe to be a recognisable discourse of writing, which can be distinguished from others, and may be in contradiction with others. For example, the skills discourse of writing is in contradiction with the process discourse of writing, since the former focuses on the product and the latter on the processes of writing, and the social practices and sociopolitical discourses of writing actively set themselves in opposition to discourses based on asocial views of writing. The horizontal dimension provides a means of identifying assumptions which underpin practice. The vertical dimension of the framework provides a way of categorising views about writing and learning to write, and recognising aspects of a comprehensive view of language (as described in the previous section) which might be missing when particular views are expressed or implied.

An important caveat about the framework is that actual texts and events may be heterogeneous, drawing on two or more discourses in complex interanimation with one another. Particularly, I would not expect an individual teacher of writing to fit neatly into a single ' row' $^{\prime}$ on the matrix. The personal approach of most teachers is eclectic: in a single lesson or a series of lessons they 
may draw on two or more discourses of writing and learning to write, incorporating two or more approaches from those I have listed, and perhaps others. In a particular context, however, it may be possible to recognise a dominant discourse at work by the way in which particular beliefs and practices are foregrounded at the expense of others.

In the following sections I will discuss in turn each 'discourse of writing' represented by a row on the matrix - and the beliefs about writing, beliefs about learning to write, approaches to the teaching of writing, and assessment criteria associated with this discourse. I will indicate existing theory and research which is relevant to each view, and draw out and discuss connections across columns and between rows, including particularly connections which a two-dimensional representation cannot encompass, as shown by the dotted arrows in Figure 2.

\section{A Skills Discourse of Writing}

Underlying a great deal of policy and practice in literacy education is a fundamental belief that writing consists of applying knowledge of a set of linguistic patterns and rules for sound-symbol relationships and sentence construction. At its most extreme, this is a belief that writing is a unitary, context-free activity, in which the same patterns and rules apply to all writing, independent of text type. In this view, what counts as good writing is determined by the correctness of the letter, word, sentence, and text formation. This extreme version of the belief that writing is (just) a set of patterns is most common in discussions of writing which are narrowly focused on words and sentences, but can refer to longer stretches of text too, with prescriptions for cohesive links and structures within and between paragraphs which are independent of text type. However, in recent times it has become more generally recognised that texts differ, at least in terms of patterns larger than sentences, and so this belief may be found in conjunction with the belief that writing is a set of text-types, shaped by social purposes (see below).

Associated with this belief about writing is a belief that learning to write involves learning the sound-symbol relationships which generate well-formed words, syntactic patterns which generate well-formed sentences, and looser patternings of cohesion within and between paragraphs which are characteristic of well-formed texts. While curricula for the teaching of writing may explicitly or implicitly draw on more than one belief about how writing is learned, I suspect that a substantial proportion of many writing curricula is founded on this belief that learning to write consists of learning a set of linguistic skills.

These beliefs lead to 'skills' approaches to the teaching of writing, which focus on the autonomous linguistic 'skills' of correct handwriting, spelling, punctuation and sentence structure. A great deal of the teaching in this approach is explicit: children are taught spelling patterns and rules for grammatically correct and correctly punctuated written sentences. They undertake exercises which draw their attention to linguistic patterns and distinctions in written language, and their writing is assessed according to how accurately these patterns have been reproduced. The explicit teaching of grammar is part of skills approaches to the teaching of writing, an example of which is the recent UK Department for Education and Skills publication Grammar for Writing (DfES, 2000). In skills approaches, 'writing' is treated as a separate 'skill' from 'reading', and curricu- 
lum documents are likely to have separate sections devoted to each. The 'study skills' approach to academic literacy instruction, as identified by Lea and Street (1998), is to a large extent a 'skills' approach in that it focuses on correct usage and adherence to conventions for the formal features of academic writing.

The term 'phonics' is associated with skills approaches to the teaching of writing, referring to the teaching of how sounds are represented by letters and letter strings. Although the word 'phonics' is related to linguistic terms such as 'phonetic', 'phonology' and 'phoneme', it is not itself a linguistic term, and several of the correspondences traditionally taught in a 'phonics' approach have a different logic from the logic of phonetics and phonology. Particularly, 'phonics' does not recognise diphthongs, has its own meaning for 'long vowels', and does not recognise reduced vowels. Teachers of 'phonics' may not know how its description of the English sound system differs from that offered by linguistic phonetics and phonology. Battles rage in public and professional media about whether 'phonics' should be used for the teaching of reading and/or for the teaching of writing, and about the intricacies of different phonic approaches for each. These may be presented as 'alternative approaches', but I suggest that they all belong to the same discourse of writing and learning to write, focusing on the learning of decontextualised linguistic rules and patterns.

School primers from the 19th and early 20th centuries embody this approach, and rival approaches, such as those described below, were not in evidence in the UK or the US until after the 1950s. Since then, this approach to the teaching of writing has had a chequered history. It has at times been completely dismissed in favour of other approaches, foregrounding different views of writing and learning to write (as discussed below), particularly in the belief that knowledge about the patterns and rules of written language are best learned implicitly. In practice, however, many teachers integrate this traditional approach to the teaching of writing with other more recent approaches, providing a varied and balanced writing curriculum.

This discourse of writing and learning to write is recognisable in references to 'skills', spelling, punctuation and grammar, in expressions such as 'correct', 'accurate', 'proper', 'learners must/should', in the explicit and prescriptive teaching of rules, and in an emphasis on accuracy in assessment. In this discourse, the focus on linguistic skills rather than on the characteristics and demands of the social context in which writing is being used leads, I suggest, to the separation of the teaching of writing from the teaching of reading. The set of beliefs and practices which constitute this discourse is well known and often features in polarised discussions of literacy education, with politicians, journalists and some researchers and teachers strongly defending it as the most important element, or even as the only significant element, in early or basic literacy education. It is a discourse which is foregrounded in times of 'moral panic' about standards and 'the state of the nation' (see Cameron, 1995; Cameron \& Bourne, 1988; Clark \& Ivanič, 1997 (Chapters 2 and 8) for discussion of this issue in the UK). There is no question that implicit knowledge of spelling patterns, of what is accepted as grammatical in written English, and of conventional punctuation is an important aspect of learning to write. Highly contested, however, are the primacy of this knowledge in relation to other aspects of writing, the way in which such knowledge is best developed, and the place of explicit teaching in this. Unfortunately, those who believe in the importance of paying pedagogic 
attention to other aspects of writing and learning to write are usually accused of dismissing this aspect completely, hence polarising the debate in a wholly unhelpful way.

\section{A Creativity Discourse of Writing}

The discourse of writing as the product of the author's creativity also focuses on the written text, but is concerned with its content and style rather than its linguistic form. In this discourse 'meaning' is central, with the writer engaged in meaning-making, and so it is concerned with mental processes as well as with characteristics of the text. Writing is treated as a valuable activity in its own right: the creative act of an author, with no social function other than that of interesting or entertaining a reader. This belief about the nature of writing generates value judgements about what counts as 'good' writing in terms of content and style, rather than, or in addition to, in terms of accuracy. I suggest that this belief about writing originates in the enjoyment of literature. Many teachers of writing are also teachers of literature, and they have learnt as students of literature to appreciate the writing of a wide range of novelists, poets, dramatists and essayists, so it is not surprising that beliefs and values from this domain carry over into the teaching of writing.

This view of writing is connected to the belief that people learn to write by writing, hence learning to write involves writing as much as possible (see, for example, Britton, 1970; Britton et al., 1975; Dixon, 1967; Elbow, 1973; Graves, 1983). This belief about learning to write has two sub-beliefs. Firstly, people write more, and therefore develop as writers more, if they have the opportunity to write on interesting, inspiring, and personally relevant topics. Secondly, reading good writing by others provides a model and a stimulus for learning to write. Thus, learning about how to write and what counts as good writing is implicit in the acts of writing and reading, rather than having to be taught explicitly.

These views had a powerful influence on the teaching of writing in the US and the UK in the 1960s and 1970s, leading to approaches which I have summarised as 'creative self-expression'. These approaches to the teaching of writing involve treating learner writers as 'authors', setting them the task of writing an 'essay' or 'composition', providing one or more stimulating topics, helping the learners to generate content and vocabulary suitable for these topics, and encouraging them to write at length on their chosen topic. Within this discourse the writing has value in its own right, so no purpose or context for writing needs to be specified, and most of the content comes from the students' own experience. For this reason, a lot of the writing produced by these teaching approaches is personal narrative, descriptions of places or events within the learners' experience, fiction based on learners' experiences, and discussions of topics about which learners have knowledge and opinions. As a result, sensitive and aware teachers of writing have championed the value of writing which represents the experience, perspectives and 'voice' of learner writers from minority and disadvantaged backgrounds, challenging elitist ideas of what counts as an interesting narrative or topic to read about.

What counts as good writing in these approaches is based on criteria drawn from literature rather than everyday functional literacy. The work is assessed for 
its content and style as much as, or sometimes instead of, its accuracy. The term 'effective' is sometimes used to refer to writing which succeeds in arousing the interest, imagination or emotions of the reader, rather than as defined in relation to the social practices discourse of writing below. Textbooks, English language examinations and anecdotal evidence indicate that, at least until the late 1970s in the UK, these teaching and assessment practices were very common, and accounts suggest that they were, and in many cases are still, common in many other countries too.

In approaches which are underpinned by these beliefs about writing and learning to write, the teaching of writing is likely to be closely allied to the teaching of reading. The main assumption underlying these approaches is that learners will find out what counts as good writing and improve their writing by being exposed to examples of good writing, by being given plenty of opportunities to write, and by getting feedback on their own writing. In this way, the teaching approach depends mainly on implicit learning, not explicit teaching, although there may be some explicit teaching of vocabulary which makes the link between reading and writing. The terms 'whole language' and 'language experience' are often used to refer to these approaches, since matters of form are always encountered in the service of meaning which is located in the learners' experience.

This discourse about writing and learning to write can be recognised in expressions such as 'creative writing', 'the writer's voice', 'story', 'interesting content', 'good vocabulary/words', and in the sorts of teaching and assessment practices described here. These beliefs and practices are often heavily criticised in education policy making and the media, and caricatured in polarised debates about literacy education as elitist, 'soft', and failing to prepare learners for the writing demands of the world of work. They are set up as the opposite extreme to 'back to basics', down-to-earth teaching for 'the real world', particularly in relation to early literacy and basic literacy education. However, I suggest that this polarisation is less in evidence in practice. Many curricula contain elements which draw on this discourse of writing and learning to write in combination with others. Experienced, eclectic teachers of writing recognise the advantage of inspiring learners to write about topics which interest them and the opportunities this provides for implicit learning, alongside explicit teaching about linguistic rules and patterns.

From a different perspective, the view of writing as the product of the writer's creativity which underpins this discourse is considered by many current literacy researchers as romantic and asocial, serving only to 'authorise disadvantage' by encouraging learners to write texts which will not be valued in the real world (see Gilbert, 1994 for this argument). It may be dismissed on these grounds as irrelevant to the teaching of writing, but it can, in my view, be complemented by more socially aware, critical views, and can have a role to play in a comprehensive conceptualisation of writing, as I discuss at the end of the paper.

The views about writing and learning to write, and the teaching and assessment practices described in this section are sometimes, confusingly, referred to as 'process writing' or 'the process approach' (see, for example, McCormack, 1990). However, I have categorised them here as 'creative self-expression' in order to distinguish them from views and approaches which focus on the practical processes of writing, which I discuss in the next section. 


\section{A Process Discourse of Writing}

In the late 1970s, cognitive psychologists proposed a model of the composing processes involved in writing with three central elements: planning, translating and reviewing, and two factors which interact with these: the writer's long-term memory and the task environment (Flower \& Hayes, 1980). This research shifted attention from the product to the processes of writing, and was concerned with processes in the mind. At this time, possibly as a direct result of this research, teachers of writing began to pay more attention to the practical processes of planning, drafting and revising writing than to the characteristics of the product. Stotsky (1990) sounded an important note of caution in her article 'On planning and writing plans - or beware of borrowed theories', warning that these two sets of processes - those in the mind and those in practice - are not the same as each other, and that the cognitive theory should not necessarily be taken as the justification for the pedagogic approaches which focus on planning, drafting and revising. In my opinion it is best to recognise that 'writing processes' can refer to either or both the cognitive and the practical processes. In the framework, I have attempted to represent this by making this view of writing span two aspects of a comprehensive view of writing (in the second column): both the mental processes and the event. The research and pedagogic initiatives concerning the processes of writing added a new way of thinking about writing to those already in play, diversifying the resources available to writing teachers.

An inevitable corollary of such a conceptualisation of the nature of writing is the view that learning to write should include learning the processes and procedures for composing a text. This view of learning to write in principle encompasses both the cognitive and the practical processes: the cognitive processes might be learned implicitly, while the practical ones are extremely amenable to explicit teaching.

These beliefs about writing and learning to write are very attractive to teachers and policy makers, because they translate into a set of elements which can be taught explicitly and which have an inherent sequence. The approach to the teaching of writing based on these views is well known as 'the process approach'. Syllabuses and textbooks since 1980 in many parts of the world have incorporated this approach, with chapters and activities devoted to generating ideas, planning, drafting, various ways of providing and working with feedback on drafts, revising and editing. This is where the focus on the mental and the focus on the practical diverge from one another: these teaching approaches are overtly concerned with the practical processes involved in writing, although nurturing the development of cognitive processes may be part of their subsidiary agenda.

It is questionable whether this aspect of writing can be assessed. When the focus in lessons is so much on the process, it seems perverse for the assessment to remain with the product. On the other hand, the process is really only a means to an end: the point of learning and improving the processes involved in writing is in order to improve the quality of the end result, not for their own sake. I have heard of some attempts to divide the assessment for writing classes which use process approaches between the quality of the process and the quality of the product so that, in principle, a learner can have engaged diligently and successfully in planning, drafting and revising, but still not have produced a high 
quality piece of writing. A compromise is to require not only a written 'composition' but also a written reflection on the processes involved in producing it, and to assess both. However, I have marked 'assessment criteria' in this discourse of writing with a question mark in the framework, since I am not convinced that there is any value or validity in assessing writing processes for their own sake, nor that it is possible to formulate criteria for them other than 'lead to a successful product'.

This discourse manifests itself in verbs and verbal nouns such as 'plan', 'draft', 'revision', 'collaborate/ion', 'editing', in other expressions referring to more sophisticated subtleties of the composing process, and in the sorts of teaching and assessment practices described here. In the 1980s, when this discourse of writing as a set of processes first made an impact on writing pedagogy, it gave rise to the 'process vs. product' dichotomy, with educators aligning themselves discoursally with one or the other, particularly in the teaching of first year composition in the US. However, this discourse is now extremely widespread, and evidence of it can be found ubiquitously, both as a dominant discourse, and in various combinations with other discourses. It does not figure in polarised debates about early literacy education in quite the same way as the preceding two discourses, at any rate in the US and the UK. This is partly, I suggest, because attention to writing processes is relatively uncontentious, and partly because this view of writing and approach to the teaching of writing is still not fully understood or recognised by many policy makers and journalists. In Australia 'the process approach' is held up in opposition to 'the genre approach' to the teaching of writing (see e.g. Reid, 1987; Stierer \& Maybin, 1994: Part 5), which I discuss in the next section. In those debates, however, the term 'the process approach' often refers to pedagogic practices which I would identify with the creativity discourse as described above, so the process discourse of writing is not really in contention.

\section{A Genre Discourse of Writing}

This discourse of writing focuses again on writing as product, but pays attention to the way in which the product is shaped by the event of which it is a part, as represented by the dotted arrow linking 'the written text' and 'the writing event' in Figure 2. In the process discourse of writing, the processes were usually associated with writing essays and compositions for their own sake (which perhaps explains the conflation and confusion of the two preceding discourses in much of the terminology and debate over literacy education in the 1980s, particularly in Australia). Beyond broad distinctions between narrative, descriptive, expository and argumentative writing, the process approach did not pay attention to differences in text-type, context and purpose for writing. The practical processes of writing are a part of the writing event, but only a small part. The view of writing as a set of text-types shaped by social context broadens the view of what is involved in writing to include also social aspects of the writing event. This view of the nature of writing originates in the work of Halliday (1978; Halliday \& Hasan, 1989) and in the way Martin (e.g. 1989) took this up and applied it specifically to the teaching of writing in primary schools. The key point in this theoretical tradition is that texts vary linguistically according to their purpose and context. As a result, it is possible to specify linguistic features of particular 
text-types according to whether they are spoken or written, whether they are recounting, describing, informing, instructing, and according to the formality and certainty of the situation. This view of writing is concerned with the written text, but also pays attention to social factors in the writing event, and uses them to take a very different perspective on the text from that described in the skills discourse above. Good writing is not just correct writing, but writing which is linguistically appropriate to the purpose it is serving.

This view of the nature of writing has a clear implication for learning to write: learners need to learn the linguistic characteristics of different text-types in order to be able to reproduce them appropriately to serve specific purposes in specific contexts. It is in principle possible to acquire this linguistic knowledge implicitly; after all, writers through the ages have learnt to adapt their writing to the demands of different social contexts without explicit teaching. However, it is a characteristic of this discourse of learning to write that this knowledge is best learnt from explicit instruction (see Christie, 1987; Martin, 1993; Martin et al., 1994; Rothery, 1989a, 1989b; Wignell et al., 1989).

These views about the nature of writing and learning to write lend themselves to pedagogical realisation, and have been translated into approaches to the teaching of writing broadly referred to as 'the genre approach', originating mainly in Australia in the mid to late 1980s. These approaches have in common the explicit teaching of the linguistic characteristics of particular text-types which serve particular social purposes, as described in publications such as those listed above. In everyday life, text-types are generated by social contexts and social purposes; in pedagogic settings, these may have to be artificially specified. The 'target' text-types are modelled, linguistic terminology is taught in order to generalise about the nature of such texts, and learners are encouraged to use this information to construct (rather than 'compose') their own texts in the same genre. There is special emphasis on teaching the features of what are thought to be 'powerful genres' - the text-types which are associated with success in educational and bureaucratic contexts: text-types which rely on a good deal of nominalisation and packing of nouns into phrases to compact meaning. In terms of Lea and Street's three approaches to the teaching of academic literacy (1998), the genre approach falls in the category of 'academic socialisation': learning the established conventions for the types of writing which are highly valued in the academy. Because of the requirement for a substantial amount of linguistic input, it is difficult to combine this method of teaching writing with others. However, in recent times there have been attempts to integrate it with methods based on more fluid, ideologically sensitive views of genre, as described below.

The dominant criterion for what counts as good writing in this discourse of learning to write is appropriacy, referring to the choice of appropriate linguistic features for a particular text-type. For assessment purposes in pedagogic settings, this means that a piece of writing with some inaccuracies and perhaps dull in terms of content and style can nevertheless be rated excellent for demonstrating the appropriate characteristics for the text-type to fulfil the specified purpose in the specified social context. The criterion of 'appropriacy' has become very common in assessment documentation, and is perhaps a welcome alternative to 'accuracy' and 'interest value'. However, it should be viewed critically, as argued by Fairclough (1992c). It is necessary to ask 'appropriate, according to 
whom?' to challenge conventions for appropriacy in the light of social and discoursal change, and to recognise alternatives to what are considered to be 'appropriate' conventions: alternatives which might better represent less dominant world views, and less privileged social groups.

The discourse of writing as a set of text-types shaped by social context is characterised by references to linguistics, names for text-types such as 'Recount', linguistic terminology such as 'nominalisation', 'passive', references to 'appropriacy', and the teaching and assessment practices described here. This approach to teaching has attracted strong opinions from teachers, policy makers and researchers, both positive and negative. On the one hand it is seen as logical, systematic, down to earth, and teachable: the opposite of 'woolly liberal' thinking about writing, as many dub the 'creative self-expression' approach. On the other hand, it is seen as prescriptive and simplistic, based on a false view of text-types as unitary, static and amenable to specification.

\section{A Social Practices Discourse of Writing}

In the beliefs about writing which underlie this discourse, the 'writing event' is much more significant than in the previous two discourses. In the process discourse of writing, the event is reduced to the writing processes themselves, and in the genre discourse of writing the role of the event is limited to shaping linguistic features. In a social practices discourse of writing, however, the text and the processes of composing it are inextricable from the whole complex social interaction which makes up the communicative event in which they are situated, and meaning is bound up with social purposes for writing. Writing is purpose-driven communication in a social context. Writing is conceptualised as a part of 'literacy' more broadly conceived as set of social practices: patterns of participation, gender preferences, networks of support and collaboration, patterns of use of time, space, tools, technology and resources, the interaction of writing with reading and of written language with other semiotic modes, the symbolic meanings of literacy, and the broader social goals which literacy serves in the lives of people and institutions. These aspects of writing are both observable elements in literacy events which are amenable to recording and documentation, and generalised, socioculturally situated literacy practices which can be inferred from such evidence.

The emphasis on the social practices in which the writing event is embedded means that this view of writing is also concerned with the broader sociocultural context of writing: the social meanings and values of writing, and issues of power. Particularly, this view of writing encompasses writing in all social and cultural contexts, rather than privileging the types of writing associated with education and other formal contexts. In this respect it overlaps with, and is often found in conjunction with, the sociopolitical discourse discussed below.

The view of writing which underlies this discourse has been developed particularly by literacy theorists in the New Literacy Studies (Barton, 1994; Barton \& Hamilton, 1998; Barton et al., 2000; Baynham, 1995; Hannon, 2000; Street, 1984, 1995), and has developed through the ethnographic study of literacy in people's everyday lives rather than from linguistic or educational theory. This has been complemented by theory and research focusing on the nature of text not just as 
linguistic substance but also as multimodal artefact, the product of the writer's design involving the interplay of more than one semiotic mode (see especially Cope \& Kalantzis, 2000; Kress, 1996, 2000; Kress \& van Leeuwen, 2001). The view of writing as social practice is a powerful theory of writing, and its pedagogic implications are more indirect than in the case of the views of writing discussed so far.

The view of how people learn to write associated with this view of the nature of writing is that they learn implicitly by participating in socially situated literacy events which fulfil social goals which are relevant and meaningful to them. This involves learning not just the composition and construction of linguistic text, but also by whom, how, when, at what speed, where, in what conditions, with what media and for what purposes texts are 'written'. Theories of learning developed within the study of 'communities of practice' (Wenger, 1998) are relevant to this discourse: people learn by apprenticeship, by 'peripheral participation' in literacy events, and by taking on the identity of community membership among those who use literacy in particular ways. Identification is a key concept (see also Ivanič, 1998) for this sort of learning: people are likely to begin to participate in particular practices to the extent that they identify themselves with the values, beliefs, goals and activities of those who engage in those practices. In contrast to the views of learning to write discussed so far, this view does not necessarily imply a role for teachers in the process: learning happens implicitly through purposeful participation, not through instruction.

These views of the nature of writing and of learning to write do not interpret easily into an approach to the teaching of writing, and one might claim that the social practices discourse of writing does not encompass any pedagogic or assessment practices. However, attention to social practices as well as the processes and products of writing can be seen to underlie three types of approach to the teaching of writing. All three can, and in my view should, be combined with a critical framing, as I describe below in relation to the sociopolitical discourse of writing.

Firstly, there are what I am calling 'functional approaches' which operate with a limited version of the views of writing and learning to write described here. These approaches to the teaching of writing involve teaching in real-life contexts, or in simulated contexts, where the emphasis is on adequate fulfilment of a specified social goal-a goal specified by someone in authority such as an employer, or imposed by bureaucracy, rather than the learner's own goal. Functional (or 'situational') approaches are likely to be found in vocational settings, aiming to prepare learners for the writing requirements of a job, or in courses preparing learners to function in particular settings in foreign or additional languages. In these approaches learners are given writing tasks which are overtly situated in a particular context, and they may be taught explicitly how to fulfil the requirements of this context.

Functional approaches to the teaching of writing do not fit neatly into the two-dimensional framework I am proposing because they span two discourses (represented by the dotted arrow between 'functional approaches' and 'skills approaches' in Figure 2). On the one hand, they are part of the social practices discourse in that they focus on more than just the linguistic rules and patterns of writing 'texts', paying attention also to contextual factors of writing 'events', 
such as the times and places for writing, who will be reading the writing, the specific characteristics of the materials and technology to be used. But on the other hand, these approaches have much in common with the skills discourse in that they are concerned with preparing learners to fulfil externally defined goals.

The other two approaches to the teaching of writing based on a view of writing as purpose-driven social interaction are less prescriptive and less narrowly focused on achieving specific functional goals. The types of approach I am summarising as 'purposeful communication' include 'the communicative approach' to language teaching which developed in the early 1980s in opposition to more form-focused approaches to language teaching. The principle of these approaches is that learners must as far as possible be involved in purposeful, situated activities which require writing in order to fulfil goals, and are subject to all the sociopolitical factors which affect real-life writing. The role of the teacher is to identify situations which contain a high degree of authentic communication, involving the full complexity of writing practices which arise in naturally occurring literacy events. The requirement to do this is very taxing on teachers, who are usually dependent on the classroom settings in which they find themselves. However, the classroom and the educational institution are, in themselves, social settings, and afford opportunities for purposeful communication to those who are alert to them. Particularly, the use of writing as a tool for learning and demonstrating learning across the curriculum is a socially situated activity involving the full complexity of social practices, and the teaching of writing can be allied to this. Information and Communication Technology provides many new opportunities for authentic communication at a distance, which thus intrinsically requires writing. Teachers may also work to build a sense of community in their classrooms, which can generate its own authentic purposes for writing (see Green \& Dixon, 1993; Santa Barbara Classroom Discourse Group, 1992; Yeager et al.,1998). As a second best, teachers holding a view of writing as purpose-driven communication in social context might set up communication activities which simulate real-life purposes and contexts for communication, as for example in the simulations in Littlejohn's simulations-based business letter writing course (Littlejohn, 2000). The activities in this book involve real-time decision making, writing under time constraints, reacting to changing (business) conditions, such as fire in the stockist's warehouse, refusal of bank credit lines, and rival quotations, such that the students, working in groups representing a company, have to make decisions and implement those decisions by writing a letter to other groups of students representing a different company. Such 'total communication' activities give learners the opportunity to learn by doing, in which a great deal of learning comes about implicitly, although teachers can draw explicit attention to aspects of the communicative practices in which students are engaging.

The third teaching approach which, I suggest, falls within this discourse of writing is one in which learners are encouraged to become ethnographers of the literacy practices of particular contexts in which they would like to participate. Approaches of this sort involve setting learners the task of studying a particular context - for example, an academic course, a workplace, or a community organisation, observing and documenting the practices and the texts which are in operation there, and generalising from these data as to what is typical of the context, 
and if possible also why things are done the way they are. This type of approach is more common in Higher Education, but possible also with learners of all ages. They will to a large extent learn directly from the research process, finding out about the practices in which they need to engage, and the texts they need to produce, from the examples they observe and collect.

Within this discourse, the criterion for what counts as good writing is effectiveness in achieving social goals, which can only be seen in the consequences of the writing, including its effects on other people. In everyday life, people are concerned only with how far their writing serves their purposes (which may include giving a good impression of themselves through neatness and correctness), not with quality judgements for their own sake. In educational settings, however, effectiveness as a criterion for assessment is hard to implement or quantify, since most assessment is undertaken by teachers or examiners in relatively decontextualised settings. The assessors may judge a piece of writing as 'effective', referring to its effectiveness at engaging the reader's interest and imagination (as in the creativity discourse of writing, above), rather than effectiveness according to a full range of social purposes. Consequently, 'effectiveness' is susceptible to being overridden by other criteria in pedagogic assessment practice. However, assessment practices which do not use comparative or normative measures, and those which take the learner's views into account, can counteract this tendency. Learners producing portfolios of evidence and 'progress files' can comment on how successfully their writing achieved their socially defined goals (as opposed to whether it met other, decontextualised criteria), and this can be taken into account in summative statements of achievement.

This discourse is characterised by references to events, contexts, purposes and practices, to people, times, places, the technologies and material resources of writing, to the visual and physical characteristics of texts. It manifests itself in a good deal of ambivalence towards the teaching and assessment of writing, with practitioners sensitive to the gulf between pedagogic and real-life settings, and dismissing many established approaches as 'decontextualised'. These problems are less of a concern for those who have harnessed this discourse to 'functional' ends for whom situatedness is a relatively straightforward and describable matter. The discourse is common in academic debate and among practitioners who have intellectually or intuitively arrived at these ways of thinking about writing and their consequences for practice. It is less common and less well understood in policy and media contexts. Insofar that it entails implicit learning, however, it is liable to be dismissed as not sufficiently focused on 'the basics'. I suggest also that there are tensions within this discourse in that theorists who associate themselves with its views of literacy and literacy learning may want to dissociate themselves discoursally from the functional approaches to teaching outlined above.

\section{A Sociopolitical Discourse of Writing}

This discourse is often found in conjunction with the previous one, as it also concerns the context of writing, but focuses on the broader, more political aspects of context. It is based on a belief that writing, like all language, is shaped by social forces and relations of power, contributes to shaping social forces which will 
operate in the future (see e.g. Clark \& Ivanič, 1997; Fairclough, 1989,1992a;Kress, $1989,1994)$, and that writing has consequences for the identity of the writer who is represented in the writing (Ivanič, 1998). In this view, writing involves drawing on socially constructed resources, both 'discourses' which represent the world in particular ways, and 'genres' which are conventions for particular types of social interaction. These discoursal and generic resources are not a rich tapestry of possibilities, neutrally available for writers to choose among, but are themselves sociopolitically structured in such a way that common sense dictates the preference of one over others in a particular context, and this preference is likely to be in the interests of more powerful social groups in that context. Decisions made by those in powerful positions influence or even dictate the discoursal and generic resources that a writer can draw on and make use of. Hence writers are not entirely free to choose how to represent the world, how to represent themselves, what social role to take, and how to address their readers when they write, but these are to some extent determined by the sociopolitical context in which they are writing. Modern versions of this 'social constructionist' view of writing are not as deterministic as this suggests, however. They include a view of the writer as also a social agent, free to draw on discourses and genres which are not privileged in the context, and to mix resources, producing heterogeneous, nonconformist texts and practices which challenge and subvert norms and conventions. In this way, individual writers can play their part in resisting and contesting the status quo, and ultimately in contributing to discoursal and social change.

The view of learning to write within this discourse is that it should include developing a critical awareness of why particular discourses and genres are the way they are: the historical and political factors which shaped them and shaped the patterns of privileging among them. These issues must be part of learning to write so that writers understand the consequences of writing in one way rather than another - of participating in particular discourses and genres. Learning to write which does not include this critical dimension would, in this discourse, seem inadequate and likely to lead to unthinking conformism which might be detrimental to the writer and/or to those he or she writes to, for, or about.

These views of writing and learning to write imply the explicit teaching of sociopolitical explanations and consequences, as has been developed in approaches known as 'Critical Literacy' or 'Critical Language Awareness' (see Clark, 1992; Clark \& Ivanič, 1991, 1998, 1999; Cope \& Kalantzis, 2000; Fairclough, 1992b; Janks, 2000). These approaches involve such things as explicitly identifying how particular linguistic and semiotic choices position writers and readers in terms of their views of the world, social roles and social relations. Alternative wordings are discussed for the change they make in how social reality is represented, the consequences for the writer's identity, and how reader-writer relations are constructed. While these 'critical' approaches to the teaching of writing have become more widespread in the 1990s, they have recently been challenged for tending to privilege a particular kind of critical rationality without attending sufficiently to the dialogic tensions inherent in writing (Lillis, 2003), or to issues of affect and desire (Janks, 2002).

Critical Literacy can be taught as a freestanding curriculum topic, or allied with other teaching approaches described in the previous section, adding and 
foregrounding sociopolitical explanations for and consequences of the practices engaged in and observed. The four-part pedagogy recommended by the New London Group (1996; see also Cope \& Kalantzis, 2000) integrates the 'Purposeful Communication' approach described above with Critical Literacy through what they call 'Critical Framing', making a link between awareness and practice. They claim that awareness opens up new possibilities for practice, as in Figure 3.

Critical Literacy also complements approaches in which learners are encouraged to become ethnographers of literacy practices, moving beyond generalisations about cultural contexts to sociopolitical explanations and positing alternatives which might better represent the interests of less privileged social groups. A critical literacy approach may include investigating what counts as 'writing' in specific social contexts: identifying the very discourses of writing which are the subject of this paper. For example, in a particular context a skills discourse of writing might dominate, and it would be in the interests of participants in that context to be aware of this and take it into account in their own actions. $^{2}$

The notion of assessment is antithetical to this discourse, since any judgement as to what counts as good writing is critically scrutinised for the relations of power which underpin it, and to identify in whose interests the assessment is being made. However, there is perhaps an unstated criterion along the lines that writing can be judged by the extent to which it works to sustain equality among the participants in the written communication, and takes social responsibility for the way in which social actors are represented by it. Certainly such criteria could not be incorporated in a marking scheme, as they are inherently subjective.

This discourse is characterised by references to politics, power, society, ideology, representation, identity, social action and social change, by the explicit pedagogy described here, and by a critical stance towards the practice of assessment. It is a discourse engaged in by academics with a social view of literacy, and by practitioners with a strong sense of the social, cultural and political location of their practice - teachers of writing whose background, I suggest, might be in cultural studies or other social sciences. The pedagogic practices which are part

1. Development of practical mastery of practices through immersion in authentic Situated Practice.

2. An awareness and understanding of these practices through Overt Instruction.

3. A capacity to critique those practices as socially particular and partial actualities from within a wider range of possibilities through Critical Framing.

4. Transformed Practice, experimentation with new practices reflexively informed by Overt Instruction and especially Critical Framing.

Figure 3 A critical view of literacy learning (adapted from the New London Group, 1996: 85-8) 
of this discourse are liable to be dismissed as political and 'ideological', as if there might be some practices which are somehow not political and ideological.

\section{Developing and Applying the Framework}

The six discourses of writing and learning to write identified here could be adapted to refer also to reading and learning to read, or to refer to literacy education in which reading and writing are integrated. I decided to focus on writing in this paper for the sake of clarity and brevity, since it requires a lot of additional terminology and complexity to include reading too. However, the 'translation' to include reading is fairly self-evident. For example, the process discourse of writing is paralleled by a process discourse of reading, in which the focus is on processes and strategies such as surveying, identification of questions to guide reading, skimming, scanning and inference. In my own research I focus on writing, learning to write, the teaching and assessment of writing, but I believe the underlying discourses I have identified are more broadly applicable to literacy research. There may also be other discourses which are relevant to literacy pedagogy. For example, it may be possible to identify discourses of learning which focus on affective factors which contrast with discourses of learning focusing on cognitive or social factors. These would interact in interesting ways with the discourses I have identified, which derive from views about language. In addition, the framework needs to be extended to take account of beliefs about writing and pedagogic practices in cultural contexts beyond the Anglophone countries on which it is currently based.

Space has not allowed me to give specific examples of how the framework might be used in research, but I am hoping that readers will envisage a variety of applications in different research contexts. Sealey's work, as described at the beginning of this paper, in my opinion provides a good example of how discourses can be identified in curricula for language and literacy education. In my own teaching I have set tasks for students to identify the discourses in operation in textbooks for the teaching of writing and in literacy education policy documents, and to identify discourses in the framework which are missing from the data. Researchers supervised by me are finding that the framework provides an analytical tool for coding interview data in which teachers of writing talk about their practice, and for coding observational data about writing teachers' pedagogic practices. What they are finding is that the people they are researching draw heterogeneously on these six discourses in ways which sometimes resolve, sometimes maintain, the tensions and contradictions among them.

\section{Towards a Comprehensive Pedagogy for the Teaching of Writing?}

My main claim for this framework is that it is a useful research tool, distinguishing among different discourses of writing, each of which is constituted by particular views of the nature of writing and of learning to write, specific ways of talking about writing, and specific pedagogic and assessment practices. Actual texts, actual curricula, people writing or talking about literacy, and observable pedagogic practices may instantiate one of these discourses, or may be hybrid instantiations of two or more of them. The multilayered view of the nature of language presented in Figure 1 was used as a way of presenting and distinguish- 
ing among these discourses, moving from a discourse based on a very restricted view of the nature of language to one in which language is much more broadly conceived.

However, the multilayered view of language presented in Figure 1 could also be seen as a basis for imagining a holistic, comprehensive writing pedagogy. In such a view of writing, written text, writing processes, the writing event, and the sociopolitical context of writing would be understood to be progressively embedded within one another, and intrinsically interrelated. The multimodal nature of written communication would be recognised in each layer: text, process, event and context (as discussed further in Ivanič, 2003). Learning to write would be conceived of as comprising all four layers. I want to suggest that all six beliefs about writing listed in the third column of Figure 2 could make a contribution to a comprehensive view of writing, that any one without the others may be an impoverished view of writing, and that the same is true of the beliefs about learning to write in the fourth column. The corollary of this is that a comprehensive approach to the teaching of writing would combine elements from all six approaches to the teaching and assessment of writing, as listed in the right-hand columns, although a teacher attempting such an integration would inevitably face some tensions and contradictions, as mentioned above. The multilayered view of language implies the possibility of a more comprehensive pedagogy than those associated with the individual discourses identified in the framework.

Thus a fully rounded pedagogy would derive from a multifaceted view of the nature of writing, which takes account of all four layers of a comprehensive view of language. A hypothetical example of practice which takes account of all six views of the nature of writing and learning is to base a series of lessons around a simulated activity which requires writing under real-life demands and constraints. This might be preceded by some research about the role of writing in the setting which has been chosen. It could then be followed by discussions of sociopolitical factors which might be at work in such a setting, of the genres that need to be drawn upon and how they are transformed in the process, of the mental and procedural processes of composition which operated for the writing which was undertaken, of the nature of creativity in the writing task and, finally, of issues of accuracy and correctness which arose, and how they were resolved. More realistically, specific teaching sequences might integrate two or more approaches, while a whole curriculum might span all six.

There are inherent contradictions between, for example, a view of writing as the decontextualised product of an author's creativity, and a view of writing as purpose-driven communication in a social context, but this does not imply that a teacher should treat writing as either one or the other - rather that both should be understood, and should be drawn upon in the light of an understanding of the other. Such discourses tend to be driven apart, I suggest, by interests vested in privileging one view of writing over others: the interests of those who will stand to gain politically or commercially from curriculum changes, from the introduction of new teaching materials, and from the adoption of one particular theoretical stance rather than another. Teachers are to a large extent at the mercy of these forces, but they have the intellectual freedom to be aware of the way in which these forces privilege one discourse at the expense of others, and to compensate 
for this if at all possible. In order to maximise what they offer to learners, I suggest that teachers of writing can benefit from being aware of the existence of all six views of writing and learning to write and the pedagogic practices associated with them, and from recognising which discourse(s) of writing they are inhabiting.

\section{Acknowledgement}

This paper has evolved from a presentation 'The discourses of writing and learning to write.' at the conference Discourses and Learning: Theoretical and Applied Perspectives, Lancaster, England, July 1999. I have benefited from feedback from participants at that conference, and also from Theresa Lillis, Peter Hannon, David Barton, Karin Tusting and many students on Language and Education courses at Lancaster University, particularly Sophie Case, Younghwa Lee, Eamon McCafferty, Mihaela Tilinca and Lining Yang. I am grateful also for valuable feedback from an anonymous reviewer for Language and Education.

\section{Notes}

1. Three of these discourses align with the three, potentially separable, factors in the 'production format' of an utterance identified by Goffman (1981:144-5): the creativity discourse of writing concerns the writer as 'author', the process discourse of writing concerns the writer as 'animator', and the sociopoliticaldiscourse of writing concerns the writer as 'principal' in Goffman's terms.

2. I am indebted to David Andrew of London Metropolitan University for drawing this point to my attention.

\section{Correspondence}

Any correspondence should be directed to Roz Ivanič, Literacy Research Centre, Department of Linguistics and Modern English Language, Lancaster University, Lancaster LA1 4YT, UK (r.ivanic@lancs.ac.uk).

\section{References}

Barton, D. (1994) Literacy: An Introduction to the Ecology of Written Language. Oxford: Blackwell.

Barton, D. and Hamilton, M. (1998) Local Literacies: Reading and Writing in One Community. London: Routledge.

Barton, D., Hamilton, M. and Ivanič, R. (eds) (2000) Situated Literacies: Reading and Writing in Context. London: Routledge.

Baynham, M. (1995) Literacy Practices: Investigating Literacy in Social Contexts. London: Longman.

Bourne, J., Kress, G., Street, B. and Sealey, A. (1999) The National Literacy Strategy: A debate. In T. O'Brien (ed.) Language and Literacies. Clevedon: British Association for Applied Linguistics in association with Multilingual Matters.

Britton, J. (1970) Language and Learning. Harmondsworth: Penguin.

Britton, J., Burgess, T., Martin, N., Mcleod, A. and Rosen, H. (1975) The Development of Writing Abilities (11-18). London: Schools Council Publications.

Cameron, D. (1995) Verbal Hygiene. London: Routledge.

Cameron, D. and Bourne, J. (1988) No common ground: Kingman, grammar and the nation. Language and Education 2 (3), 147-59.

Christie, F. (1987) Genres as choice. In I. Reid (ed.) The Place of Genre in Learning: Current Debates. Geelong: Centre for Studies in Literary Education, Deakin University.

Clark, R. (1992) Principles and practice of CLA in the classroom. In N. Fairclough (ed.) Critical Language Awareness. London: Longman. 
Clark, R. and Ivanič, R. (1991) Consciousness-raising about the writing process. In P. Garrett, and C. James (eds) Language Awareness in the Classroom. London: Longman.

Clark, R. and Ivanič, R. (1997) The Politics of Writing. London: Routledge.

Clark, R. and Ivanič, R. (1998) Critical discourse analysis and educational change. In L. van Lier and D. Corson (eds) The Encyclopedia of Language and Education, Volume 6: Knowledge About Language. Dordrecht: Kluwer.

Clark, R. and Ivanič, R. (1999) Guest editors, and Introduction: Raising critical awareness of language: A curriculum aim for the new millennium. Language Awareness 8 (2), 6370.

Cope, B. and Kalantzis, M. (eds) (2000) Multiliteracies: Literacy Learning and the Design of Social Futures. London: Routledge.

Department for Education and Skills (DfES) (2000) Grammar for Writing. London: DfES.

Dixon, J. (1967) Growth through English. London: Oxford University Press.

Elbow, P. (1973) Writing without Teachers. London: Oxford University Press.

Fairclough, N. (1989) Language and Power. London: Longman.

Fairclough, N. (1992a) Discourse and Social Change. Cambridge: Polity.

Fairclough, N. (ed.) (1992b) Critical Language Awareness. London: Longman.

Fairclough, N. (1992c) The appropriacy of 'appropriateness'. In N. Fairclough (ed.) Critical Language Awareness. London: Longman.

Flower, L. and Hayes, J. (1980) Identifying the organization of writing processes. In L. Gregg and E. Steinberg (eds) Cognitive Processes in Writing. Hillsdale, NJ: Erlbaum.

Gee, J. (1996) Social Linguistics and Literacies: Ideology in Discourses (2nd end) (first published 1990). London: Falmer.

Gilbert, P. (1994) Authorizing disadvantage: Authorship and creativity in the language classroom. In B. Stierer and J. Maybin (eds) Language, Literacy and Learning in Educational Practice. Clevedon: Multilingual Matters.

Goffman, E. (1981) Forms of Talk. Oxford: Blackwell.

Graves, D. (1983) Writing: Teachers and Children at Work. London: Heinemann Educational.

Green, J. and Dixon, C. (1993) Introduction to special issue on 'Talking knowledge into being: Discursive and social practices in classrooms'. Linguistics and Education 5 (3\&4), 231-40.

Halliday, M.A.K. (1978) Language as Social Semiotic: The Social Interpretationof Language and Meaning. London: Edward Arnold.

Halliday, M.A.K. (1994) An Introduction to Functional Grammar (2nd edn) (first published 1985). London: Arnold.

Halliday, M.A.K. and Hasan, R. (1989) Language, Context and Text: Aspects of Language in a Social-Semiotic Perspective (First published 1985, Victoria: Deakin University Press). Oxford: Oxford University Press.

Hannon, P. (2000) Reflecting on Literacy in Education. London: RoutledgeFalmer.

Ivanič, R. (1998) Writing and Identity: The Discoursal Construction of Identity in Academic Writing. Amsterdam: John Benjamins.

Ivanič, R. (2003) The teaching of 'wrighting': literacy education in a multimodal world. Paper presented at the Literacy and Education Research Network Conference on Learning, Institute of Education, London, July.

Janks, H. (2000) Domination, access, diversity and design: A synthesis model for critical literacy education. Educational Review 52 (2), 175-86.

Janks, H. (2002) Critical literacy: Beyond reason. Australian Researcher 29 (1), 7-27.

Jones, N. (1990) Reader, writer, text. In R. Carter (ed.) Knowledge about Language and the Curriculum: The LINC Reader. London: Hodder and Stoughton.

Kress, G. (1989) Linguistic Processes in Sociocultural Practice (first published 1985, Victoria: Deakin University Press). Oxford: Oxford University Press.

Kress, G. (1994) Learning to Write (2nd edn) (first published 1982) London: Routledge.

Kress, G. (1996) Representational resources and the production of subjectivity. In C.R. Caldas-Coulthard and M. Coulthard (eds) Texts and Practices: Readings in Critical Discourse Analysis. London: Routledge.

Kress, G. (1997) Before Writing: Rethinking the Paths to Literacy. London: Routledge. 
Kress, G. (2000) 'You've just got to learn how to see': Curriculum subjects, young people and schooled engagement with the world. Linguistics and Education 11 (4), 401-15.

Kress, G. and van Leeuwen, T. (1996) Reading Images: The Grammar of Visual Design (2nd edn) (First published 1990, Victoria: Deakin Press). London: Routledge.

Kress, G. and van Leeuwen, T. (2001)Multimodal Discourse: The Modes and Media of Contemporary Communication. London: Arnold.

Lea, M. and Street, B. (1998) Student writing in higher education: An academic literacies approach. Studies in Higher Education 23 (2), 157-72.

Levine, K. (1985) The Social Context of Literacy. London: Routledge and Kegan Paul.

Lillis, T. (2003)Student writing as 'academic literacies': Drawing on Bakhtin to move from critique to design. Language and Education 17 (3),192-207. Also presented at the International Literacy Conference, Literacy and Language in Global and Local Settings, Cape Town, November 2001.

Littlejohn, A. (2000) Company to Company. A Communicative Approach to Business Correspondence in English (3rd edn). Cambridge: Cambridge University Press.

Martin, J. (1989) Factual Writing: Exploring and Challenging Social Reality (first published 1985, Victoria: Deakin University Press). Oxford: Oxford University Press.

Martin, J. (1993) Literacy in science: Learning to handle text as technology. In M. Halliday and J. Martin (eds) Writing Science: Literacy and Discursive Power. London: Falmer.

Martin, J., Christie, F. and Rothery, J. (1994) Social processes in education: A reply to Sawyer and Watson (and others). In B. Stierer and J. Maybin (eds) Language, Literacy and Learning in Educational Practice. Clevedon: Multilingual Matters.

McCormack, R. (1990) Genre and process. Adult Literacy and Basic Skills Unit Newsletter 37, 6-7.

New London Group (1996) A pedagogy of multiliteracies: Designing social futures. Harvard Educational Review 66 (1), 60-92. Reprinted in Cope and Kalantzis (eds) (2000) Multiliteracies: Literacy Learning and the Design of Social Futures (pp. 9-37). London: Routledge.

Ormerod, F. and Ivanič, R. (2002) Materiality in children's meaning-making practices. Journal of Visual Communication 1 (1), 65-91.

Reid, I. (ed.) (1987) The Place of Genre in Learning: Current Debates. Geelong: Centre for Studies in Literary Education, Deakin University.

Rothery, J. (1989a) Writing to learn and learning to write. In J. Martin (ed.) Factual Writing: Exploring and Challenging Social Reality (first published 1985, Victoria: Deakin University Press). Oxford: Oxford University Press.

Rothery, J. (1989b) Learning about language. In R. Hasan and J. Martin (eds) Language Development: Learning Language, Learning Culture. Norwood, NJ: Ablex. (Advances in Discourse Processes 27-Meaning and choice in language: Studies for Michael Halliday).

Santa Barbara Classroom Discourse Group (Green, J., Dixon, C., Lin, L., Floriani, A., Bradley M., Paxton, S., Mattern, C, and Bergamo, H.) (1992) Constructing literacy in the classroom: Literate action as social accomplishment. In H. Marshall (ed.) Redefining Learning: Roots of Educational Change. Norwood, NJ: Ablex.

Sealey, A. (1997) Models of language, models of childhood in the English National Curriculum. Changing English 5 (1), 69-81.

Sealey, A. (1999a) Theories about Language in the National Literacy Strategy. Coventry: Centre for Elementary and Primary Education, University of Warwick.

Sealey, A. (1999b) Teaching primary school children about the English language: A critique of current policy documents. Language Awareness 8 (2), 84-97.

Stierer, B. and Maybin, J. (eds) (1994) Language, Literacy and Learning in Educational Practice. Clevedon: Multilingual Matters.

Stotsky, S. (1990) On planning and writing plans - or beware of borrowed theories. College Composition and Communication 41 (1), 37-57.

Street, B. (1984) Literacy in Theory and Practice. Cambridge: Cambridge University Press.

Street, B. (1995) Social Literacies:Critical Perspectiveson Literacy in Development, Ethnography and Education. London: Longman.

van Leeuwen, T. (1998) It was just like magic: A multi-modal analysis of children's writing. Linguistics and Education 10 (3), 273-305. 
Wenger, E. (1998) Communities of Practice: Learning, Meaning, and Identity. Cambridge: Cambridge University Press.

Wignell, P., Martin, J., and Eggins, S. (1989) The discourse of geography: Ordering and explaining the experiential world. Linguistics and Education 1 (4), 359-91.

Yeager, B., Floriani, A. and Green, J. (1998) Learning to see learning in the classroom: Developing an ethnographic perspective. In D. Bloome and A. Egan-Robertson (eds) Students as Researchers of Culture and Language in their own Communities. Cresskill, NJ: Hampton. 